\title{
Трансдисциплинарность как направление развития современного градостроительства
}

\author{
Ю.П.Бочаров, РААСН, Москва \\ Н.Н.Жеблиенок, СПбГАСУ, Санкт-Петербург \\ М.А.Жеблиенок, Лаборатория градопланирования, Санкт-Петербург
}

Статья посвящена вопросу развития принципов дисциплинарного взаимодействия в градостроительстве. Перечень дисциплин, составляющих научную основу градостроительства, часто становился предметом исследования отечественных авторов, но принцип организации взаимодействий и обеспечение междисциплинарной иерархии имеющимися исследованиями почти не затронуты. Авторский коллектив систематизировал отечественные модели организации дисциплинарного взаимодействия в градостроительстве. Выделены важнейшие этапы эволюции дисциплинарных взаимодействий, которые по аналогии с зарубежной практикой названы «многодисциплинарный» - «междисциплинарный» и «трансдисциплинарный».

«Многодисциплинарная» модель интеграции опирается на возможности суммирования знаний из различных научных областей специалистом-градостроителем. Эта модель предполагает крайне ограниченное количество дисциплин и остро ставит вопрос физической возможности освоения всего круга знаний одним специалистом. В дальнейшем эта модель была усовершенствована и во всем мире получила распространение идея «междисциплинарной» интеграции, которая предполагает существование нескольких профилей в профессии градостроителя. Дисциплинарный синтез реализуется за счет формирования междисциплинарных исследований, появлением новых пограничных областей научного знания.

В настоящий момент «трансдисциплинарная» модель определена как наиболее актуальная. На основании модели «трансдисциплинарных» взаимодействий предложена концепция современной структуры градостроительства. Систему градостроительных знаний предлагается рассматривать как часть системы общечеловеческих знаний, сконцентрированную вокруг сложного гетерогенного объекта - искусственной среды обитания. В этом случае границы градостроительного знания трактуются как адаптирующиеся в зависимости от условий конкретного объекта градостроительной деятельности. Концепция позволяет учесть динамичный характер постоянно расширяющего перечня научных дисциплин, причисляемых к системе градостроительных знаний, а также принимает во внимание разнообразные формы активности (участие жителей, общественных организаций, инициативы представителей

${ }^{1}$ Исследование выполнено в рамках Государственной программы Российской Федерации «Развитие науки и технологий» на 2013-2020 годы по Плану фундаментальных научных исследований Минстроя России и РААСН, тема №5.1.6/4.2.13. разных уровней власти), которые в современном мире составляют весомую часть градостроительства ${ }^{1}$.

Ключевые слова: градостроительство, профессия градостроителя, структура градостроительной науки, трансдисциплинарность.

Transdisciplinarity as a Direction for Development of Modern Urban Planning

Yu.P.Bocharov, RAACS, Moscow

N.N.Zheblienok, SPSUACE, Saint Petersburg

M.A.Zheblienok, Laboratory of urban planning, Saint Petersburg

The article is devoted to the development of the principles of disciplinary cooperation in urban planning. The list of disciplines that make up the scientific basis of urban planning has often become the subject of research by domestic authors, but the principle of organizing interactions and ensuring an interdisciplinary hierarchy with existing research is almost not affected. The team of authors has systematized domestic models of organizing disciplinary cooperation in urban planning. The most important stages of the evolution of disciplinary interactions, which by analogy with foreign practice are called "multidisciplinary", "interdisciplinary" and "transdisciplinary", are highlighted.

The "multidisciplinary" integration model relies on the ability of a city planner to summarize knowledge from various scientific areas. This model assumes an extremely limited number of disciplines and sharply raises the question of the physical possibility of mastering the whole range of knowledge by one specialist. At alater stage this model was improved and the idea of "interdisciplinary" integration became widespread throughout the world, which implies the existence of several profiles in the profession of a city planner. Disciplinary synthesis is realized through the formation of interdisciplinary research, the emergence of new border areas of scientific knowledge.

The "transdisciplinary" model is identified as the most relevant. Based on the model of "transdisciplinary" interactions, the concept of a modern structure of urban planning has been proposed. The system of town planning knowledge is proposed to be considered as part of the system of universal knowledge, concentrated around a complex heterogeneous object - an artificial habitat. In this case, the boundaries of urban planning knowledge are interpreted as adapting, depending on the 
conditions of a particular object of urban planning activity. The concept allows to take into account the dynamic nature of the ever-expanding list of scientific disciplines attributed to the system of urban planning knowledge, and also takes into account various forms of activity (participation of residents, public organizations, initiatives of representatives of different levels of government), which in the modern world constitute a significant part of urban planning.

Keywords: urban planning, profession of urban planners, structure of urban planning science, transdisciplinarity.

Градостроительная деятельность всегда объединяла усилия разных систем знаний и представителей разных специальностей, но методика осуществления этой интеграции исследована крайне незначительно. Несмотря на то, что в XX веке был создан ряд концепций, описывающих «составные элементы» градостроительства, вопрос функционирования устойчивых связей между дисциплинами оставался открытым [1].

Профессия планировщика городов сложилась в первой половине XX века. В Англии Королевский институт городских планировщиков был основан в 1914 году, в США первая национальная Конференция градостроителей состоялась в 1909 году, а Гарвардский университет начал выпускать дипломированных планировщиков в 1929-ом. Американское общество планировщиков возникло в 1934 году, затем было создано около тридцати факультетов и колледжей, специализирующихся на подготовке дипломированных специалистовпланировщиков и инженеров градостроительного профиля.

В первой четверти XX века российские инженеры А.П. Иваницкий, М.Д. Загряцков и другие предложили создать систему подготовки градостроительных кадров, объединяющую три направления: архитектурное, инженерное и экономическое [2]. Сначала в Петрограде, а потом и в Москве были открыты специализированные учебные подразделения, обучающие студентов планировке городов, городскому и сельскому благоустройству, транспорту и коммунальному хозяйству. Предполагалось, что выпускаемые инженеры будут работать совместно с архитекторами-планировщиками. Однако эти учебные подразделения в условиях централизованного планирования оказались невостребованными [2].

Идея объединения в интересах решения градостроительных задач представителей различных специальностей развивалась за счёт подготовки новых профессиональных организаций урбанистов. Первое Общество архитекторовурбанистов (АРУ) возникло в 1928 году [3]. СНК СССР одобрил проведение в Москве всемирного конгресса урбанистов, и, если бы конгресс состоялся в Москве, принятая на нём хартия могла стать Московской. К сожалению, в последний момент въезд в страну иностранным делегатам был запрещён, и всемирный конгресс урбанистов состоялся в 1933 году в Афинах, где и была принята Афинская хартия.
Второе общество урбанистов (СОУ - Советское общество урбанистов) было создано в 1987 году. Оно объединяло архитекторов, экономистов, географов, управленцев, экологов, философов. Были определены цели общества: восстановление связей страны с международными обществами планировщиков; разработка методики междисциплинарной оценки градостроительных проектов; подготовка системы обучения и сертификации дипломированных планировщиков в 14-ти республиканских подразделениях СОУ. В 1989 году в Москве и Переславле-Залесском прошло первое в СССР Международное совещание урбанистов. В 1990 году в Варшаве СОУ было принято в состав Всемирного общества городских и региональных планировщиков (ISOCARP). В связи с распадом CCCP в 1992 году общество было ликвидировано. Впоследствии ряд членов общества урбанистов (А. Высоковский и другие) создали систему профессиональной подготовки урбанистов в рамках Высшей школы экономики в Москве.

Однако развитие идеи полипрофессиональности градостроительства не находит отображения в современных законодательных инициативах. В стандарте «Градостроитель» (2016) в перечне трудовых функций градостроителя находим «организацию планирования и проектирования обустройства территорий, проведение исследований и изысканий... для разработки... градостроительной документации и... техническое сопровождение разработки градостроительной документации». Ограничение роли градостроителя «разработкой градостроительной документации» и «обустройством территории» противоречит ожиданиям общественности, возлагающей на градостроительство ответственность за устойчивое сбалансированное развитие российских городов.

Пока градостроительство трактуется исключительно как часть индустрии созидания, строительства, освоения, множество важнейших явлений, других развивающихся дисциплин оказываются во «вне-профессиональном» вакууме. Отсутствие концепции, в которой любое направление градостроительных исследований станет частью единой системы знаний, потворствует некритичному копированию зарубежных моделей организации градостроительной деятельности, поощряет внутренний раскол, в конечном итоге - ослабляет позиции всего российского градостроительства.

Для разных этапов развития градостроительства характерны различные принципы организации дисциплинарных взаимодействий. Например, у В.Н. Семёнова и М.Г. Диканского синтез дисциплин внутри науки «градостроения» или «градостроительства» реализовывался, если можно так сказать, «линейно», то есть описывался как простая сумма знаний [4]. Изначально понимание дисциплинарного синтеза в градостроительстве сводилось к определению перечня входящих в его состав дисциплин. В настоящее время в англоязычных исследованиях этот период именуется «многодисциплинарным» (англ. - multidisciplinary) [1; 5]. Многодисциплинарная интеграция дисциплин фактически сохраняет их автономность, объединение систем знаний 
происходит в результате сочетания разнообразных навыков и знаний специалистом-градостроителем [6]. Основным инструментом такой дисциплинарной интеграции фактически становится специалист-планировщик (в дореволюционной практике - преимущественно гражданский инженер, в советской практике после 1930 годов - архитектор-планировщик).

В 1930-е годы проблема нарастания объёмов градостроительного знания обсуждалась в советской печати [7] в контексте сложности подготовки «универсала-планировщика». В.И. Боберко, А.П. Иваницким и рядом других авторов была предложена «иерархическая» концепция главенствования архитектуры и «подчинение» ей «не архитектурных» дисциплин.

Следует упомянуть два источника, которые поражают воображение глубиной их взгляда: текст устава Общества архитекторов-урбанистов АРУ (руководитель - Н.А. Ладовский) и статья Л.А. Ильина «Эволюция градостроительства» (1921). Ильин пишет «...теперь придётся не столько строить дома, сколько города и даже системы городов, обустраивать... области. В градостроительстве теперь и государству, и коммунам, и городским общинам придётся идти рука об руку, помня, что без этого единения ничто не может быть создано». Фактически предлагается рассматривать взаимодействие не только разных типов знания, но и разных форм активности - профессионалов, власти, горожан. В тексте устава АРУ вскользь упоминается «...необходимость создания высшего... учебного заведения для изучения всей суммы вопросов, связанных с градостроением» [3]. Город упоминается как «наукообразующий» фактор, лежащий в основе организации системы профессионального образования. Примечательно, что в уставе АРУ градостроительство упоминается как форма профессионального знания, а урбанистика - как его непрофессиональная форма (одной из задач АРУ обозначена «... организация существующих курсов по градостроительству в специальных учебных заведениях и введение курса по урбанизму в общественных вузах» [3]).

Несмотря на то, что с содержательной точки зрения послевоенное издание книги «Градостроительство» (авторы А.В. Бунин, Л.А. Ильин, Н.Х. Поляков, В.А. Шквариков) сформулировало иной перечень дисциплин, составляющих основы градостроительства - они были направлены в большей мере на решение художественно-идеологических задач - идея организации синтеза дисциплин осталась почти незатронутой [4]. Позже в работах В.Л. Глазычева, 3.Н. Яргиной, В.В. Владимирова, Т.Ф. Саваренской, И.М. Смоляра перечень включаемых в состав градостроительства научных областей был расширен.

Появление новых дисциплин, освоение которых становилось неотъемлемой частью квалификации градостроителя, обусловило необходимость главным инструментом дисциплинарного синтеза рассматривать систему профессионального образования. На неё, а также на последипломное самообразование планировщика и возлагалась ответственность за реализацию в практической деятельности дисциплинарной синергии. Но уже в 1960-е - 1970-е годы стало очевидным, что такого рода синтез не может быть обеспечен градостроителем как неким универсальным зодчим, понимающим всю сложность структуры города и способном ею управлять. Зарождение экономгеографии, развитие основ геоинформационных систем, популяризация ментального анализа в социологии города $[5 ; 6]$ повлекли за собой коренные изменения в принципе организации дисциплинарных взаимодействий. Ряд зарубежных исследователей (например, Nigel Taylor [5]) высказывают мнение, что глубокий разрыв между градостроительством и архитектурой произошёл именно в 1960-е - 1970е годы на фоне перемещения вектора понимания города от его физической пространственной сущности (что роднило задачи архитектуры и градостроительства) в плоскость понимания города как суммы разнообразных видов деятельности в условиях частной собственности на землю и имущество.

В СССР своеобразным ответом на эти явления стало возращение в 1970-х годах в русскоязычные работы термина «урбанистика». Например, в аннотации к работе Дж. Форрестера «Динамика развития города» (1974) сообщалось, что «...книга представляет значительный интерес для экономико-географов, урбанистов, градостроителей, экономистов». «Урбанистика» упоминалась в основном как система знаний, объединяющих в процессе изучения и решения городских проблем представителей самых разных специализаций. «Многодисциплинарная» модель интеграции дисциплин постепенно трансформировалась в «междисицплинарную» модель (англ. - interdisciplinary) [5; 6]. «Междисциплинарность» подразумевает наличие «командной» проектной работы, когда профессионалы из нескольких смежных областей участвуют в принятии общих градостроительных решений.

На рубеже XX-XXI веков на градостроительство начинают оказывать влияние политические явления (демократизация; нарастание практики «участия граждан»; развитие нового типа «участия общества» в виде экологических инициатив, общественных движений в поддержку маломобильных граждан и т.д.). Нарастание процессов урбанизации делает необходимым также учёт так называемого «неявного знания» (англ. - tacit knowledge), проявляющегося в виде комплекса градостроительных знаний каждого горожанина, негласной системы ценностей и поведенческих установок, сформированных для жизни в крупных городах мира. Широкое распространение получает непрофессиональная практика сбора и обработки статистических данных в области градостроительства, используемых по принципу краудсерфинга. «Градостроитель» начинает выступать «как системный интегратор» [8] знаний о среде обитания горожан, играет роль координатора общественных интересов.

Междисциплинарное градостроительное знание XX века опиралось на имеющийся каркас научных дисциплин. Для начала XXI века характерно нарастание двух параллельных процессов: усложнение понимания проблем искусственной среды обитания, то есть внутренней структуры объекта градо- 
строительной деятельности, сопровождается усложнением её субъектной структуры. Это привело к критике междисциплинарной модели взаимодействий внутри градостроительства:

1) инструментом реализации «междисциплинарной» модели был так называемый «комплексный подход», основанный на идее максимального учёта самых разрозненных данных о рассматриваемом градостроительном объекте объём этих данных, их принципиальная несводимость друг к другу и отсутствие реальных моделей для их совместного учёта привели к жёсткой критике этого подхода [9] и позднее - к признанию его несостоятельности [10]

2) нарастание объёмов градостроительных дисциплин реально не привело к росту прозрачности происходящих в городах процессов: «недостатка в исследованиях города нет... однако состояние нынешнего этапа изучения города характеризуется энциклопедичностью результатов, нежели их философской законченностью» [11]; многими учёными была озвучена проблема целостности градостроительного знания

3) результатом междисциплинарных взаимодействий на практике становились документы: стратегии развития, генеральные планы, проекты долгосрочного развития терри- ториальных объектов - с течением времени стало понятно, что их разработка требует огромного количества ресурсов, а их выполнение не превышает 10\% [12]

4) взаимодействие профессионалов - представителей различных наук в реальной практике сильно усложняется за счёт разности идеологических установок, терминологической базы, принципов и ценностей, которых придерживаются независимые научные дисциплины [13; 14]

5) «междисциплинарная» модель не позволяла учитывать нарастающие объёмы непрофессионального участия в градостроительстве.

Структура и смысловые границы градостроительства в связи с кризисом системы междисциплинарных взаимодействий также подвергалась серьёзной критике [5; 6]. Многие исследователи ставили под сомнение факт существования самостоятельной науки о градостроительстве, в основном по причине невозможности описания её структуры на языке общепринятых академических дисциплин. Разработка концепции «трансдисциплинарной» $[1 ; 5 ; 6]$ модели построения взаимодействий в градостроительстве была направлена на устранение этих противоречий (табл. 1).

Таблица 1. Междисциплинарные и трансдисциплинарные взаимодействия в градостроительстве: последствия реализации в свете современных вызовов

\begin{tabular}{|c|c|c|}
\hline \multirow{2}{*}{$\begin{array}{l}\text { Современные «вызовы» в градо- } \\
\text { строительстве }\end{array}$} & \multicolumn{2}{|c|}{ Принцип дисциплинарного взаимодействия } \\
\hline & Междисциплинарная модель & Трансдисциплинарная модель \\
\hline $\begin{array}{l}\text { Рост объёмов (и роли) непрофес- } \\
\text { сионального участия в решении } \\
\text { градостроительных задач }\end{array}$ & $\begin{array}{l}\text { Проблемы интеграции значи- } \\
\text { тельной доли реальных участни- } \\
\text { ков градостроительной деятель- } \\
\text { ности в её структуру }\end{array}$ & $\begin{array}{l}\text { Признание легитимности разных форм гражданских } \\
\text { инициатив, возможность их интеграции в систему } \\
\text { градостроительной деятельности }\end{array}$ \\
\hline $\begin{array}{l}\text { Резкое снижение результатив- } \\
\text { ности в процессе производства } \\
\text { градостроительной документации } \\
\text { («стандартного проектирования») }\end{array}$ & $\begin{array}{l}\text { Проблемы учёта всех типов } \\
\text { общественных инициатив, ин- } \\
\text { дивидуальных уникальных гра- } \\
\text { достроительных задач }\end{array}$ & $\begin{array}{l}\text { Гибкие подходы в отношении состава и содержания } \\
\text { проектной документации, возможность индивиду- } \\
\text { ального подхода к перечню привлекаемых научных } \\
\text { дисциплин }\end{array}$ \\
\hline $\begin{array}{l}\text { Неудовлетворённость общества } \\
\text { скоростями реакции на обществен- } \\
\text { ные инициативы, потребности, } \\
\text { запросы }\end{array}$ & $\begin{array}{l}\text { Рост общественного разочарова- } \\
\text { ния в отношении процесса про- } \\
\text { изводства градостроительной } \\
\text { документации }\end{array}$ & $\begin{array}{l}\text { Оформление на уровне профессиональных и об- } \\
\text { разовательных стандартов новых типов градострои- } \\
\text { тельной деятельности - например, «градостроитель- } \\
\text { координатор», «градостроитель-инноватор» }\end{array}$ \\
\hline $\begin{array}{l}\text { Несоответствие российских про- } \\
\text { фессиональных и образовательных } \\
\text { стандартов в области градострои- } \\
\text { тельства мировым трендам и на- } \\
\text { циональным интересам }\end{array}$ & $\begin{array}{l}\text { Формирование профессиональ- } \\
\text { ных и образовательных стан- } \\
\text { дартов на основе устаревающих } \\
\text { представлений о градострои- } \\
\text { тельстве как сумме иерархически } \\
\text { соподчинённых дисциплин }\end{array}$ & $\begin{array}{l}\text { Актуализированная концепция градостроительства } \\
\text { как динамично развивающегося перечня научных } \\
\text { дисциплин, интеграция между которыми происхо- } \\
\text { дит по принципу бионической саморегулируемой } \\
\text { системы }\end{array}$ \\
\hline $\begin{array}{l}\text { Рост количества научных дис- } \\
\text { циплин и областей знания, зани- } \\
\text { мающихся вопросами градостро- } \\
\text { ительства }\end{array}$ & $\begin{array}{l}\text { Трудность использования «ком- } \\
\text { плексного подхода» для об- } \\
\text { работки колоссальных объёмов } \\
\text { разнодисциплинарных данных. }\end{array}$ & $\begin{array}{l}\text { Признание за градостроительством динамических } \\
\text { и адаптивных характеристик, признание факта } \\
\text { существования системы неопределённостей (см. } \\
\text { концепцию Ю.М. Моисеева) и «неочевидного» } \\
\text { градостроительного знания (см. концепцию «ви- } \\
\text { димого спектра градостроительных проблем» А.В. } \\
\text { Крашенинникова) }\end{array}$ \\
\hline
\end{tabular}


«Трансдисциплинарность» подразумевает отказ от границ научных дисциплин в пользу работы со сложными гетерогенными явлениями [5; 14]. Предвидимая почти сто лет назад Н.А. Ладовским концентрация «всей суммы вопросов, связанных с градостроением» фактически реализована: границы отдельных дисциплин и наук преодолены, и это позволяет увидеть градостроительство как систему знаний, образованную и удерживаемую в виде единства не за счёт академической сплочённости наук, а за счёт единства объекта - города. Процесс эволюции принципов дисциплинарного синтеза в градостроительстве может быть проиллюстрирован на примере сравнительного анализа нескольких широко известных моделей (рис. 1).

Рассмотрим модель И.М. Смоляра (рис. 1 а) - «многодисциплинарность» этой модели носит всеобъемлющий характер: в работе обсуждается 18 научных дисциплин и более 150-ти комплексных «сочетаний» - тем, объединяющих несколько научных направлений [15]. Характерно, что в модели принцип взаимодействия этих научных дисциплин и направлений не имеет «центра», сводится к условному «объединению» данных из разных дисциплин.

Модель, предлагаемая Ю.П. Бочаровым [2] на основании североамериканских программ в области градостроительного образования (рис. 1 б), может рассматриваться как следующий шаг, актуализирующий «многодисциплинарную» модель, - «междисциплинарный» синтез дисциплин реализуется посредством создания условий для совместного проектного творчества команды представителей различных профилей градостроительной специализации. Каждая из упоминаемых

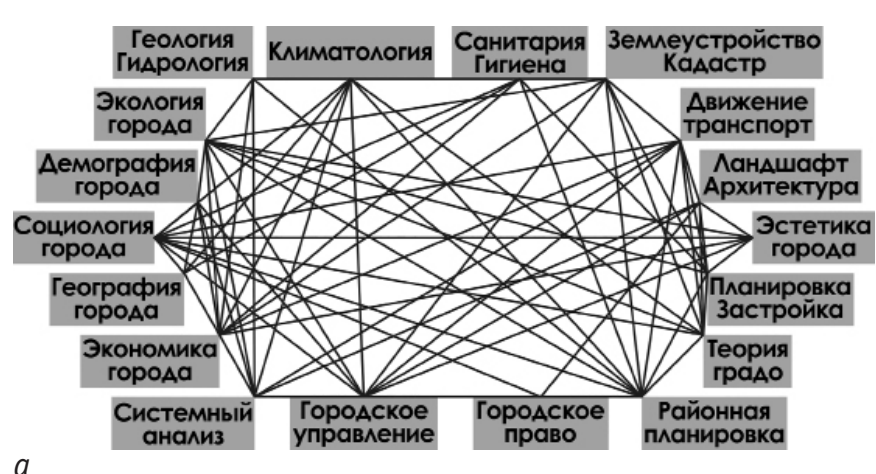

$a$

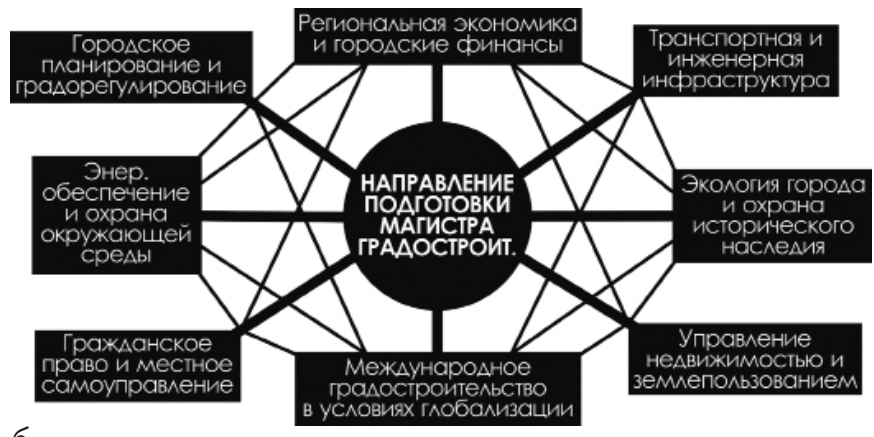

6

Рис. 1. Разные типы дисциплинарного взаимодействия в градостроительстве: а) «многодисциплинарная» модель И.М. Смоляра [15]. 2004 год; б) «междисциплинарная» модель по материалам англоязычных программ подготовки градостроителей [2]. 2006 год; в) «трансдисциплинарная» модель организации учебного процесса в ВШУ А.А. Высоковсого [16]. 2011 год научных областей сама по себе комплексная научная область, пересечение интересов между которыми и создаёт поле «градостроительства».

Наконец, модель, иллюстрирующая некоторые идеи А.А. Высоковского (рис. 1 в) развивает идею многоуровневости и типологической сложности градостроительного знания. «Трансдисциплинарность» этой модели раскрывается за счёт её многоуровневости и многоступенчатости - в частности, введения «адаптационных дисциплин»: идеологически программа подготовки в Высшей школе урбанистики (Москва) отличается от иных градостроительных школ своей гибкостью и настроенностью на «ситуативную» подготовку будущего профессионала в области градостроительства в зависимости от типа его образования. Признание за своим учащимся права не иметь базовой архитектурной подготовки [16] и готовность «адаптировать» будущего урбаниста в ходе обучения выделяет ВШУ из общего массива градостроительных учебных заведений страны.

Саморегулируемость состава проектных работ, гибкость в формировании перечня дисциплин, способность к интеграции любого необходимого объёма новых знаний в зависимости от потребности заказчика и города - это признаки «трансдисциплинарной» модели современного градостроительства, в основе которой - нацеленность на достижение высокого уровня адаптивности в условиях уникальных индивидуальных градостроительных задач. В других российских городах также реализуется целый ряд интересных трансдисциплинарных инициатив, например, сессии Международного Байкальского зимнего градостроительного университета [17] в Иркутске

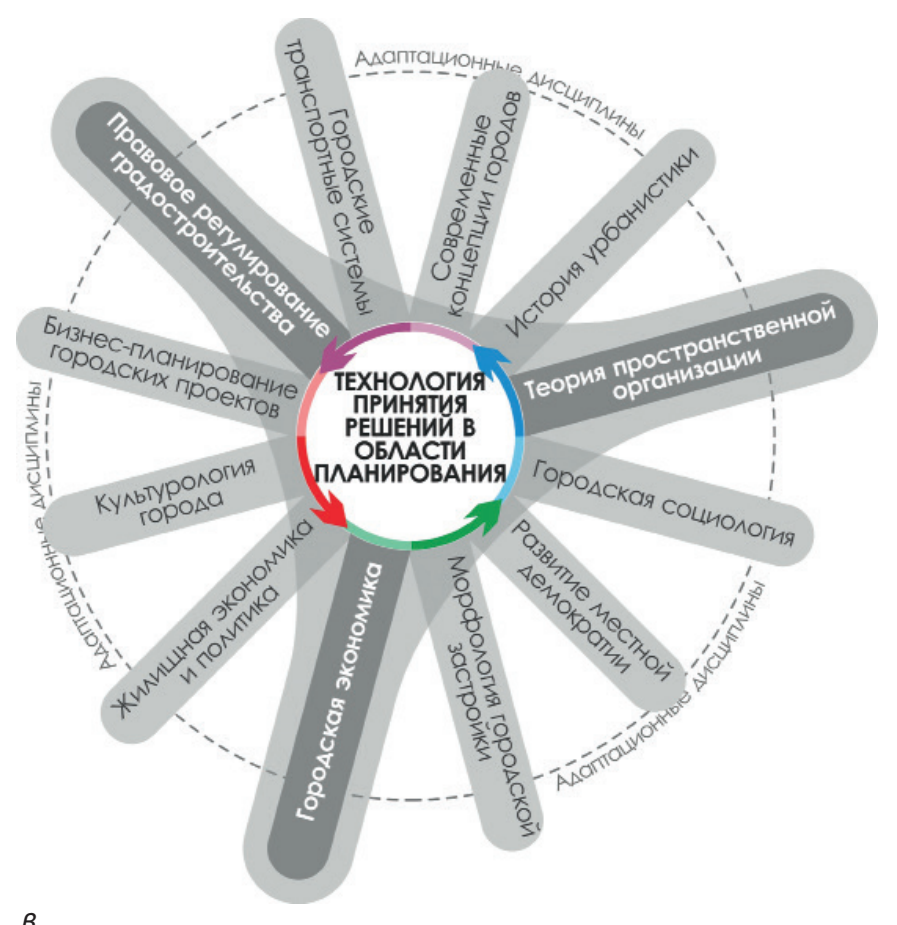

8 
(под методологическим руководством члена-корреспондента PAACH М.Г. Мееровича) и научных школ «Преобразование транспортно-коммуникационных пространств городов» в Санкт-Петербурге (идеолог - М.Л. Петрович).

Отдельный интерес представляют инструменты реализации разных моделей дисциплинарного взаимодействия. «Многодисциплинарная» модель предполагала применение в градостроительстве коэффициентов, расчётных методик, моделей из разных дисциплин. На практике это были разрозненные показатели [19], сведение которых к «единому знаменателю» теоретически могло осуществиться только за счёт их ограниченного количества и высочайшей квалификации специалиста-планировщика [14]. К таким показателям могут быть отнесены: площадь застройки, плотность уличнодорожной сети, процент застройки, плотность населения [19]. «Междисциплинарная» модель обусловила появление более сложных качественных характеристик градостроительного объекта [19]. Например, коэффициент FAR (аббревиатура от англ. «Floor Area Ratio» - так называемый «коэффициент площади пола», отражающий соотношение между площадью здания и земли (в зависимости от плотности дорожной сети) и служащий инструментом регулирования «объёма» застройки, то есть только при меньшей площади застройки есть возможность строительства большего числа этажей) [20], FSI (аббревиатура от англ. «Floor Space Index» - индекс площади пола) и т.д. Это параметры, позволяющие сравнивать результаты градостроительной деятельности в разных городах или районах одного города. «Трансдисициплинарная» модель стимулирует возникновение коммуникационного поля и универсального «языка», на котором эксперты могут быть поняты населением [19]. Трансдисциплинарность ориентирована на достижение сложных ситуативно сформулированных целевых показателей - «безопасности», «региональной идентичности» - а не показателей, удобных для конкретной науки. Примером могут служить такие параметры, как оценка «качества/уровня общественных связей» [19], уровень привлекательности территории [19], разнообразие функций [19], распределение ответственности за ДТП между участниками движения [21] и т.д.

Эволюция процессов междисциплинарного взаимодействия в градостроительстве обусловлена усилением влияния социально-политических процессов на ход урбанизации [14; 18; 22]. Динамичное усложнение объекта градостроительства - искусственной среды обитания - провоцирует расширение «радиуса» его притяжения, который к настоящему времени уже преодолел рамки профессиональной заинтересованности экспертов и формирует вокруг себя поле «открытого» урбанистического широкодоступного знания. Важным компонентом представлений о современном градостроительстве становится понимание, что градостроительная деятельность (вне зависимости от типа её специализации) может рассматриваться как часть «поперечного сечения» комплекса совместно развивающихся научных дисциплин. Разные типы градостроительной деятельности выступают интегрирующим фактором, объединяющим достижения научных дисциплин и обеспечивающим коммуникацию между ними.

Концепцию трансдисциплинарной природы градостроительного знания следует рассматривать как основу дальнейших дискуссий и исследований, в процессе которых будут уточнены границы её применения, оценены возможные преимущества и недостатки.

\section{Лumepamypa}

1. Petrişor, A. Multi-, Trans - and Interdisciplinarity, Essential Conditions for the Sustainable Development of Human Habitat // Petrisor A.//Urbanism. Architecture. Constructions. - №4. - P. 43-50.

2. Бочаров, Ю.П. 0 подготовке дипломированных планировщиков и инженеров градостроительного профиля / Ю.П. Бочаров, М.С. Шумилов // Градостроительство в век информатизации: сб. науч. статей. - М., 2006.

3. Хан-Магомедов, С.О. Архитектура советского авангарда. В 2 кн. Кн. 2. Социальные проблемы / С.0. Хан-Магомедов. М.: Стройиздат, 2001. - 712 с.

4. Бочаров, Ю.П. Теория градостроительства как система научных знаний в работах российских инженеров и архитекторов XX века [Электронный ресурс] / Ю.П. Бочаров, Н.Н. Жеблиенок, М.А. Жеблиенок // Architecture and Modern Information Technologies. - 2017. - № 4 (41). - C. 219-230 [Электронный ресурс]. - Режим доступа: http://marhi.ru/ AMIT/2017/4kvart17/16_bocharov_zheblienok/index.php (дата обращения 15.09.2018).

5. Després, C. Implementing Transdisciplinarity: Architecture and Urban Planning At Work / C. Després, G. Vachon, A. Fortin; N. Janssens\& I. Doucet (éds), Transdisciplinary knowledge production in architecture and urbanism // Urban and Landscape Perspectives. - 2011. - Vol. 11. - P. 33-49.

6. Pinson D. Urban Planning: An 'Undisciplined' Discipline? / D. Pinson // Futures. - Vol 36. - P. 503-513.

7. Боберко, В.И. Профили специалистов-планировщиков.// Планировка и строительство городов. - 1933. - № 8. - С. 3-5.

8. Сарнацкий, Э.В. Градостроитель как системный интегратор когнитивного подхода к социально-экономическому обустройству территории / Э.В. Сарнацкий // Вопросы профессионализма в территориальном планировании: сборник научных статей. - М.-Ростов-н/Д, 2012.

9. Лаврик, Г.И. Подготовка научных кадров - кардинальная проблема градостроительства настоящего и будущего / Г.И. Лаврик, О.И. Реутов, Т.Н. Щербакова // Градостроительство. - 2013. - № 6 (28). - С. 36-41.

10. Энгель, Б. Градостроительное образование в эпоху перемен / Б. Энгель, В. Козлов // Известия вузов. Инвестиции. Строительство. Недвижимость. - 2016. - № 4 (19). - С. 190-201.

11. Межевич, М.Н. Социальное развитие и город / М.Н. Межевич // М.: Наука, 1979.

12. «Исключение как правило. Как меняются подходы к городскому планированию» [Электронный ресурс] // 
Moscow urban forum - 2018. Официальный сайт. - Режим доступа: http://mosurbanforum.ru/events/195 (дата обращения 19.09.2018).

13. Reflecting on two years of interdisciplinary research together [Электронный ресурс] //Urban green adaptation diary. - Режим доступа: https:// https://urbangreenadaptationdiary. wordpress.com/2018/06/17/ (дата обращения 17.08.2018).

14. Klein, J.T. Applying Interdisciplinary Models to Design, Planning, and Policy-making // Knowledge In Society. - Winter 1990/91. - Vol. 3. - Issue 4. - P. 29-56.

15. Основы комплексной междисциплинарной научной программы «Теория города». - М.: РОХОС, 2004. - 56 с.

16. Высоковский, А.А. 0 Высшей школе урбанистики /А.А. Высоковский // Проект Россия. Журнал о «Сколково»и иородской среде. - 2012. - Март. - С. 36-38.

17. Бочаров, Ю.П. Междисциплинарное обучение градостроителей в Иркутском университете / Ю.П. Бочаров //Фундаментальные исследования РАACH по научному обеспечению развития архитектуры, градостроительства и строительной отрасли Российской Федерации в 2010 году: сб.научн.трудов. - М.-Орёл: РААСН, 2011. - 412 с.

18. Меерович, М.Г. Рождение соцгорода. Градостроительная политика в СССР 1926-1932 гг. / М.Г. Меерович. - Иркутск: Изд-во ИрГТУ, 2008. - 472 с.

19. Peri-urban landscapes in metropolitan areas: using transdisciplinary research to move towards an improved conceptual and geographical understanding [Электронный реcypc] / Loupa Ramos I., M. Ferreiro, C. Colaco, S. Santo; Proceeding of the AESOP_ACSP joint congress. 15-19 July 2013, Dublin // ResearchGate. - Режим доступа: https://www.researchgate.net/ publication/303541342 (дата обращения 14.09.2018).

20. Yokley, E.C. Zoninglaw and practice / E.C. Yokley; fourth edition. - 1968.

21. Стратегия транспортной безопасности [Электронный ресурс] // VisionZero. - Режим доступа: https:// visionzeronetwork.org/about/what-is-vision-zero/ (дата обращения 16.09.2018).

22. Hall, $P$. Cities in Civilization: Culture, Technology and Urban Order. - N-Y: Pantheon Books, 1998. - 1169 p.

23. Соколов, Л.И. Урбанистика и архитектура городской среды / Л.И. Соколов. - М.: Академия, 2014 - 268 с.

\section{Literatura}

2. Bocharov Yu.P. 0 podgotovke diplomirovannyh planirovshhikov i inzhenerov gradostroitel'nogo profilya / Yu.P. Bocharov, M.S. Shumilov // Gradostroitel'stvo v vek informatizatsii sb. nauch. statej. - M.:, 2006.

3. Han-Magomedov S.O. Arhitektura sovetskogo avangarda. V 2 kn. Kn. 2. Sotsial'nye problemy / S.0. Han-Magomedov. - M.: Strojizdat, 2001. - $712 \mathrm{~s}$.

4. Bocharov Yu.P. Teoriya gradostroitel'stva kak sistema nauchnyh znanij $v$ rabotah rossijskih inzhenerov $i$ arhitektorov XX veka [Elektronnyj resurs] / Yu.P. Bocharov,
N.N. Zheblienok, M.A. Zheblienok // Architecture and Modern Information Technologies. - 2017. - № 4 (41). - S. 219-230 [Elektronnyj resurs]. - Rezhim dostupa: http://marhi.ru/ AMIT/2017/4kvart17/16_bocharov_zheblienok/index.php (data obrashheniya 15.09.2018).

7. Boberko V.I. Profili spetsialistov-planirovshhikov. // Planirovka i stroitel'stvo gorodov. - 1933. - № 8. - S. 3-5.

8. Sarnatskij E.V. Gradostroitel' kak sistemnyj integrator kognitivnogo podhoda k sotsial'no-ekonomicheskomu obustrojstvu territorii / E.V. Sarnatskij // Voprosy professionalizma $v$ territorial'nom planirovanii: sbornik nauchnyh statej. - M.-Rostov-n/D, 2012.

9. Lavrik G.I. Podgotovka nauchnyh kadrov - kardinal'naya problema gradostroitel'stva nastoyashhego i budushhego / G.I. Lavrik, O.I. Reutov, T.N. Shherbakova // Gradostroitel'stvo. 2013. - №6 (28). - S.36-41.

10. Engel' $B$. Gradostroitel'noe obrazovanie v epohu peremen / B. Engel', V. Kozlov // Izvestiya vuzov. Investitsii. Stroitel'stvo. Nedvizhimost'. - 2016. - № 4 (19). - S. 190-201.

11. Mezhevich M.N. Sotsial'noe razvitie i gorod // M.N. Mezhevich // M.: Nauka, 1979.

12. «Isklyuchenie kak pravilo. Kak menyayutsya podhody k gorodskomu planirovaniyu» [Elektronnyj resurs] // Moscow urban forum - 2018. Ofitsial'nyj sajt - Rezhim dostupa: http:// mosurbanforum.ru/events/195 (data obrashheniya 19.09.2018).

15. Osnovy kompleksnoj mezhdistsiplinarnoj nauchnoj programmy «Teoriya goroda». - M.: ROHOS, 2004. - $56 \mathrm{~s}$.

16. Vysokovskij A.A. 0 Vysshej shkole urbanistiki /A.A. Vysokovskij // Proekt Rossiya. Zhurnal o «Skolkovo» i gorodskoj srede. - 2012. - Mart. - S. 36-38.

17. Bocharov Yu.P. Mezhdistsiplinarnoe obuchenie gradostroitelej v Irkutskom universitete / Yu.P. Bocharov // Fundamental'nye issledovaniya RAASN po nauchnomu obespecheniyu razvitiya arhitektury, gradostroitel'stva i stroitel'noj otrasli Rossijskoj Federatsii v 2010 godu: sb.nauchn. trudov. - M.-Orel: RAASN, 2011. - $412 \mathrm{~s}$.

18. Meerovich M.G. Rozhdenie sotsgoroda. Gradostroitel'naya politika v SSSR 1926-1932 gg. / M.G. Meerovich. - Irkutsk: Izdvo IrGTU, 2008. - $472 \mathrm{~s}$.

19. Peri-urban landscapes in metropolitan areas: using transdisciplinary research to move towards an improved conceptual and geographical understanding [Elektronnyj resurs] / Loupa Ramos I., M. Ferreiro, C. Colaco, S. Santo; Proceeding of the AESOP_ACSP joint congress. 15-19 July 2013, Dublin // ResearchGate. - Rezhim dostupa: https://www. researchgate.net/publication/303541342 (data obrashheniya 14.09.2018).

21. Strategiya transportnoj bezopasnosti [Elektronnyj resurs] // VisionZero. - Rezhim dostupa: https://visionzeronetwork. org/about/what-is-vision-zero/ (data obrashheniya 16.09.2018).

23. Sokolov L.I. Urbanistika i arhitektura gorodskoj sredy / L.I. Sokolov. - M.: Akademiya, 2014 - 268 s. 
Бочаров Юрий Петрович, 1926 г.р. (Москва). Доктор архитектуры, профессор, академик РААСН. Главный научный сотрудник ЦнИИП Минстроя России (Москва, пр. Вернадского, 29). Сфера научных интересов: градостроительство, архитектура, образование в сфере градостроительства, историко-культурное наследие. Автор более 360 научных работ, в т.ч. 10 монографий. Тел.: +7 (916) 243-20-44. E-mail: albocharova28@gmail.com.

Жеблиенок Михаил Андреевич, 1988 г.р. (Санкт-Петербург). Главный инженер 000 «Лаборатории градопланирования» (190013, Санкт-Петербург, наб. реки Фонтанки, 108, б/ц «Фонтанка 108», офис 1). Сфера научных интересов: градостроительство, территориально-транспортное планирование, коммуникационные процессы в городах, проблемы немоторизованного движения. Автор более 20 научных публикаций. Тел.: +7 (950) 006-68-88. E-mail: zheblienok@gmail.com.

Жеблиенок Наталья Николаевна (Санкт-Петербург). Кандидат архитектуры, доцент, советник РААСН. Доцент кафедры «Городского хозяйства, геодезии, землеустройства и кадастров» ФГБОУ В0 «Санкт-Петербургский государственный архитектурно-строительный университет» (190005, Санкт-Петербург, 2-я Красноармейская ул., 4. СПбГАСУ). Сфера научных интересов: образование в сфере градостроительства, история профессии «градостроитель», коммуникационные процессы в городах, проблемы пешеходного движения. Автор более 30 научных публикаций, в т.ч. 2 монографий. Teл.: +7 (911) 941-13-80. E-mail: shesternevann@gmail.com.

Bocharov Yuri Petrovich, born in 1926 (Moscow). Doctor of Architecture, Professor, Academician of RAACS. Chief Researcher at the Central Institute for Research and Design of the Ministry of Construction and Housing and Communal Services of the Russian Federation (29 Vernadsky Ave, Moscow. TsNIIP). Research interests: urban planning, architecture, education in the field of urban planning, historical and cultural heritage. The author of more than 360 scientific publications, incl. 10 monographs. Tel.: +7 (916) 243-20-44. E-mail: albocharova28@gmail.com.

Zheblienok Mikhail Andreevich, born in 1989 (St. Petersburg). Chief engineer at the M.L. Petrovich Laboratory of Urban Planning (190013, St. Petersburg, Fontanka river emb., 108, business center "Fontanka 108", office 1). Research interests: structure of urban planning science, transport systems of cities, urban communication processes, problems of non-motorized mobility. Tel.: +7 (950) 006-68-88. E-mail: zheblienok@gmail.com.

Zheblienok Natalia Nikolaevna (St. Petersburg). Candidate of Architecture, Assistant Professor. Assistant Professor at the Department of Municipal Management, Geodesy, Land Management and Cadastres of the Saint Petersburg State University of Architecture and Civil Engineering (190005, St. Petersburg, 2-ya Krasnoarmeiskaya St., 4. SPbGASU). Research interests: education in the field of urban planning, the history of the urban planner profession, communication processes in cities, the problem of pedestrian traffic. The author of more than 30 scientific publications Tel.:+7 (911) 941-13-80. E-mail: shesternevann@gmail.com. 